\title{
Renegotiations of femininity throughout the constitutional debates in Turkey: representative claims in 2014 presidential elections
}

\author{
Sezen Yaras $^{\mathrm{a}, \mathrm{b}}$ and Ahu Yigit ${ }^{\mathrm{c}}$ \\ aDepartment of Political Science and Public Administration, Bilkent University, Ankara, Turkey; ${ }^{b}$ Inter-Curricular \\ Courses Department, Cankaya University, Ankara, Turkey; Independent Researcher, Washington, DC, USA
}

\begin{abstract}
In August 2014, for the first time in the history of the Turkish Republic, the president was elected through a popular vote. The quest for a new constitution and revisions to the political system were the main topics that the three presidential candidates, Recep Tayyip Erdogan, Ekmeleddin Ihsanoglu and Selahattin Demirtas, raised during their presidential campaigns. Women's problems and issues were among the central topics through which the matters of the new constitution and the revisions to be made in the system were addressed. Through a qualitative content analysis of the campaign material, this article maps the candidates' approaches to women's interests and the roles the candidates promised to play to promote these interests and roles. The findings indicate that motherhood, daughterhood and sisterhood are the key terms through which the candidates formulated the ultimate purpose of their gender-related agenda. They simply blamed the existing constitution as the main cause of alienated motherhood, polarized daughterhood and complicit femininity respectively. Based on the analysis of these simultaneous calls for heightening-disavowal of certain femininities, the article argues that competing projects for the (re)establishment of the constitutional regime in Turkey can be construed as renegotiations of feminine attachments to political authority.
\end{abstract}

\section{Introduction}

In August 2014, for the first time in the Republic's history, the Turkish president was elected through a popular vote. The change from a parliamentary vote in favour of a popular vote was the result of a constitutional amendment in 2007. The amendment was introduced in response to the political crisis of 2007, which made it impossible for the governing Justice and Development Party (Adalet ve Kalkınma Partisi, AKP) to elect a candidate to the office. The candidacy of one of the founding figures of the AKP, Abdullah Gul, 'led to the abortion of the election process by the intervention of the Constitutional Court in April 2007, following 
a warning by the Turkish armed forces about anti-secular activities.' While the previous constitutions conceived of the presidency as a rather symbolic office with very few substantive political powers, ${ }^{2}$ the current constitutional regime, which was established in 1982, gives the president 'the power to promulgate laws and ratify treaties, while enjoying exclusive authority in other areas. 3 Such authority for the president brought an intensification of concerns about the possible implications of the presidential office's being held by someone from a political party the founders of which have an Islamist background. However, the measures taken by the military and the Constitutional Court in the name of protecting secularism in the country meant a deadlock for the parliamentary government system. As a response, the AKP made certain arrangements for the direct popular election of the president and then called for a new parliamentary election. ${ }^{4}$ This process once again generated discussions about how to redefine the constitutional regime and the system of checks and balances that was established after the 1980 coup d'état. In a sense, being the first popular presidential election, the 2014 election campaign became a critical venue to discuss the governmental system and the distribution of power in Turkey.

Women's problems and issues emerged as one of the major topics through which the proposals of the candidates for a renewed constitutional order and legitimacy were discussed. Serving the best interests of women in Turkey was a common reference in the election campaigns of all three of the candidates. It is not unusual for women to be at the centre of political debates during periods of significant political transformations such as revolutions, state formations or constitution-making processes. The depictions of and the solutions offered for women's problems become central issues when the founding principles of a given political community are questioned and reformulated. ${ }^{5}$ Women constitute a particular group who are addressed for mobilization and whose attachment to competing projects of such reformulation is sought.

The attempt to reformulate women's roles and status during such periods of renewing or redefining collective identity is an important issue of interest in the scholarly literature. This particular interest in women in periods of social or political transformation has been read as projects for 'remaking' women', ${ }^{6}$ or top-down impositions by the state, as these attempts do not evolve as a result of demands originating from within the society as a whole. ${ }^{7}$ Other scholars who question the reading of these processes as top-down impositions have problematized women's consent and contribution, without which these intentions of 'remaking' could not work. The source of this consent has been read as women's bargaining with patriarchy to gain certain economic and political rights during these periods of political transformation in return for declaring loyalty and gratitude to the new morals as women. ${ }^{8}$

\footnotetext{
'Canan Aslan-Akman, 'The 2011 Parliamentary Elections in Turkey and Challenges Ahead for Democratic Reform Under a Dominant Party System', Mediterranean Politics 17, no. 1 (2012): 81.

2Ergun Ozbudun, The Constitutional System of Turkey (New York: Palgrave Macmillan, 2011): 73-96.

${ }^{3}$ Gamze Cavdar, 'Behind Turkey's Presidential Battle', Third World Resurgence 201 (2007): 36.

${ }^{4}$ Ali Carkoglu, 'A New Electoral Victory for The 'Pro-Islamists' Or The 'New Centre-Right? The Justice and Development Party Phenomenon in the July 2007 Parliamentary Elections in Turkey', South European Society \& Politics 12, no. 4 (2007): 511. ${ }^{5}$ Nilufer Gole, 'The Gendered Nature of the Public Sphere', Public Culture 10, no. 1 (1997): 61-3.

'Lila Abu-Lughod, 'Feminist Longings and Postcolonial Conditions', in Remaking Women: Feminism and Modernity in The Middle East, ed. Lila Abu-Lughod (New Jersey: Princeton University Press, 1998), 8.

7Jenny B. White, 'State Feminism, Modernization and the Turkish Republican Woman', NWSA Journal 15, no. 3 (2003): 145.

${ }^{8}$ Deniz Kandiyoti, 'Bargaining with patriarchy', Gender and Society 2, No. 3, (1988): 274-290; Simten Cosar and Metin Yegenoglu, 'New Grounds for Patriarchy in Turkey? Gender Policy in The Age Of AKP', South European Society and Politics 16, No. 4 (2011): 555-573.
} 
While attempts are made to dissolve the existing sovereign regime, women are offered certain rights and are extended freedoms from the institutions and customs that keep them bound to certain traditions and communities. However, these freedoms come with the price that once this mobilization is over and another sovereign regime is sought to be established, women's conducts, 'souls and bodies' become issues of surveillance and they turn into 'hostages of these projects'. ${ }^{\prime}$

The concept of bargaining involves an assumption that behind this voluntary 'hostageship' of women, there is an anxiety about losing the newly attained gains and freedoms. Thus, what is defined as a gain is always based on certain images of femininity as something to be left in the past, as victimhood and suppression. Those women who do not experience the new regime as liberation are defined either as miscalculating their interests, hence in need for the guidance of liberated women, or as threats to the gains accomplished with a harsh struggle. The concept of 'bargaining with patriarchy' problematizes how the chances for women's seeking furthering of their rights are limited. Anxieties about the threats posed by other experiences of femininity and the ways such gender-based hierarchies operate within their imaginary provide an important context to analyse the possible limits on the way of seeking further liberation.

By using Sirman's concept of 'active negotiation' of the feminine sense of self, ${ }^{10}$ in this article, an attempt will be made to question how each of the new constitutional models offered in the presidential elections of 2014 involves invitations for women to experience a new, distinct and 'true' form of femininity. Thus, the process will be read as negotiations with women through offering them new roles and status in the candidates' respective constitutional proposals. Different formulations of these roles lead to competing proposals to obtain women's consent and alliance with their political project. Sirman uses the concept of negotiation to define the processes where 'the subject considers various story lines and tries to make sense of self ... through entering into negotiations with history, society and culture' which, in the end, makes certain subject positions possible and desirable and turns others into 'excluded or repudiated sites'.11 Thus, it is important to analyse these positions as invitations to a distinct way of experiencing a sense of gendered selfhood and how pain, suffering, victory and compassion operate it. What are the gendered storylines that are available for women in the new constitution-making process in Turkey? How do they formulate new subject positions for women to renegotiate their sense of femininity and reconsider their gendered attachments to state authority? How are different, competing positions negated as undesirable, excess, inadequate femininities within each other's narrations?

The candidates in the 2014 presidential election process introduced models proposing alternative distributions of power among the government branches. It is through these models that they promised to work for the improvement of women's status: a presidential system for Recep Tayyip Erdogan, a reformed parliamentary system for Ekmeleddin Ihsanoglu and decentralized governance through radical democracy for Selahattin Demirtas. Despite

\footnotetext{
${ }^{9}$ Deniz Kandiyoti, 'Identity and its Discontents', Dossier 26 (2004): 46-7.

${ }^{10}$ Nukhet Sirman, 'Writing the Usual Love Story', in Gender, Agency, and Change: Anthropological Perspectives, ed. Victoria Goddard (New York: Routledge, 2000), 251.

${ }^{11}$ Ibid.
} 
the common emphasis on increased representation of women, ${ }^{12}$ the candidates differed in terms of where they locate the main sources of woman's problems, what they propose to resolve them and what kind of roles they attribute to the president who will win the popular vote in this process. Each candidate defined women's interests and status in the renewed definition of polity radically differently. These descriptions can be placed on a wide spectrum from paternal to non-paternal state authority or from cultural restoration through active state support for mothers to bringing an end to state feminism. In this study, the analysis of competing constructions of new gender identities within the constitutional proposals of the presidential candidates is the aim. The idea is to open into discussion how different narrations for re-establishing and maintaining state authority are gendered and how critical these gender-based references are for (re)newing attachments to political authority. The findings indicate that motherhood, daughterhood and sisterhood are the terms through which the role and status of women are defined in the presidential candidates' respective constitutional proposals. The article argues that while presenting these terms to be constitutionally established, these proposals also make claims about the unnatural, immoral, exclusionary, polarizing, complicit or militaristic femininities of the past which are to be disavowed for establishing a'new' collective identity. The previous constitutional establishment is criticized as the cause of alienated motherhood, polarized daughterhood and complicit femininities. Based on the analysis of these simultaneous calls for disavowal-heightening of certain femininities, the article argues that competing projects for (re)establishment of constitutional regime in Turkey can be read as renegotiations of feminine attachments to political authority in Turkey.

\section{The study and the methodology}

Since late 1990s, a great deal of scholarly work on the political developments in Turkey has started with a diagnosis about her national identity crisis. The references to the increasing alienation from the West-oriented secular regime ${ }^{13}$ and the questions about how to refashion national identity after the rise of the Islamist movement and the Kurdish insurgency are the concerns behind this diagnosis. ${ }^{14}$ In this context, what became an important debate was the formal narration about Turkish women's emancipation by the formation of the Republic. In the words of Cosar and Yegenoglu, 'Republican patriarchy hegemonised the discourse on women's emancipation until the late 1980s with the claim that Turkish women had been emancipated from the clutches of tradition-connoting the Ottoman Empire and Islamic

\footnotetext{
${ }^{12}$ In a nutshell, all three candidates emphasized the necessity for increased female participation in social, political and cultural aspects of life. Erdogan stressed the precautionary measures taken within the AKP against those who put impediments on more women's playing active roles in politics as a proof of his support for more women's becoming active politicians (Recep Tayyip Erdogan,'Presentation of Election Vision Document' (Secim Vizyon Belgesi Sunumu), (Halic Congress Center, Istanbul, July 11, 2014). Ihsanoglu on the other hand indicated his vision of a country where women can gain access to the positions they deserve in politics and the workforce. Ekmeleddin Ihsanoglu, moderated by Ahu Ozyurt, 'Association for the Support and Training of Women Candidates (KADER) Meetings with the Presidential Candidates (Kadın Adaylari Destekleme Dernegi (KADER) Cumhurbaskani Adaylari lle Bulusmalar)' (Dedeman Hotel, Istanbul, July 17, 2014). Demirtas described the current system as patriarchal and indicated the need to change the patriarchal perspective of policy-making. Selahattin Demirtas, 'Macka Meeting with Women' (Macka Park, Istanbul, July 30, 2014).

${ }^{13}$ Dogu Ergil, 'Identity Crisis and Political Instability in Turkey', Journal of International Affairs 54, no. 1 (2000): 43.

${ }^{14}$ Umit Cizre Sakallioglu, 'Rethinking the Connections Between Turkey's “Western” Identity versus Islam', Critique: Journal for Critical Studies of the Middle East 7, no. 12 (1998): 3.
} 
way of life-and became equal citizens of the Republic.'15 Muftuler-Bac, while problematizing the representation of Turkey as 'the only modern, democratic, Islamic country ... and the status of Turkish women's visibly marking this difference', argued that this narration of women's emancipation is 'one of the best concealed lies in Turkey' among other lies about its being modern and democratic. When this is exposed as a 'lie', what replaces it is 'women's predicament' in Turkey. ${ }^{16}$ As Turkish women's secondary status in social, political and cultural life was stressed to refute this formal narration, the ideal of women's emancipation was maintained and translated into the agendas of political parties. The gender-based characteristics of the previous regime were marked as subordinating women by turning them into obedient servants of the Republican ideology. ${ }^{17}$ To change the subordinating elements of the regime, women as historical actors were called for action to be involved in the process of reformulating national identity to make the state actually representative of their interests.

In this context, the AKP and its conservative democracy project that had a distinct gender agenda came to power in 2002. The party's stance towards women had been an issue of attention not only for those who stress its Islamist and anti-secular agenda but also for those who claim that AKP's conservative democracy agenda represents a turn in the history of Islamism and its approach to women's roles in social and political life. Active engagement of Islamic women within the party and the display of their sensitivity about issues on gender discrimination and representation have been acknowledged. ${ }^{18}$ The AKP was formed by those who claim to distance themselves from the Islamist orientations of the Welfare Party (Refah Partisi, RP), which was banned by the Constitutional Court in 1998 due to its anti-secular activities. The high degree of women's mobilization in support for RP was later on followed by significant criticisms among these women themselves due to their exclusion from decision-making mechanisms. ${ }^{19}$ Despite emerging out of the National Outlook (Milli Gorus) version of Islamism, the AKP's particular attention on the active roles and status of women within the party has been highlighted by the party founders themselves as one of the most distinctive elements of the AKP version of political Islam. This has also been acknowledged by certain feminists whose perception of and the ways of being perceived by political Islam have, as indicated by Arat, a very peculiar history in the Turkish context. Actually, it was the Kemalist women rather than the feminists who reacted against the Islamic revival until the women themselves from the Islamist circles started to problematize gender hierarchies within the movement and the party. ${ }^{20}$ As also acknowledged in the feminist literature, the AKP was successful in mobilizing those women who were alienated from the RP. For example, Yegenoglu and Cosar have indicated that,

\footnotetext{
${ }^{15}$ Cosar and Yegenoglu, 'New Grounds for Patriarchy in Turkey?', 558.

${ }^{16}$ Meltem Muftuler-Bac,'Turkish women's predicament'. Women's Studies International Forum 22, no. 3. (1999): 313.

${ }^{17}$ Yildiz Ecevit, 'Women's Rights, Women's Organizations and the State', in Human Rights in Turkey, ed. Zehra Kabasakal (Philadelphia: University of Philadelphia Press, 2007): 191.

${ }^{18}$ Ayse Gunes Ayata and Fatma Tutuncu, 'Party Politics of the AKP (2002-2007) and the Predicaments of Women at the Intersection of the Westernist, Islamist and Feminist Discourses in Turkey', British Journal of Middle Eastern Studies 35, no. 3 (2008): 363-84; Yesim Arat, 'Religion, Politics and Gender Equality in Turkey: implications of a democratic paradox?', Third World Quarterly 31, no. 6 (2010): 869-84.

${ }^{19}$ Yesim Arat, 'Feminists, Islamists, and Political Change in Turkey'. Political Psychology 19, no. 1 (1998): 117-31.

${ }^{20}$ Yesim Arat, 'The project of modernity and women in Turkey', in Rethinking Modernity and National identity in Turkey, ed. Sibel Bozdogan and Resat Kasaba (Seattle, WA: The University of Washington Press, 1997), 107-8.
} 
The AKP's approach to the women differs from the National Outlook movement especially in terms of the party's enthusiasm for women's public visibility. ... In the case of AKP the women found the grounds for more visibility in regular and parliamentary politics. ${ }^{21}$

On the other hand, the continuing limits on women's participation in decision-making processes after the AKP came to power, ${ }^{22}$ an obvious shift of the party to an anti-feminist rhetoric $^{23}$ and attempts to replace the gender equality agenda with a 'gender justice ${ }^{24}$ that refers to women's and men's natural differences brought serious concerns about the attitude of the party. The presidential elections corresponded to a period when the early rhetoric of the party stressing a gender equality and human rights perspective radically shifted to an anti-equality and anti-feminist line. Within Erdogan's rhetoric about women, the family is depicted as the building block of a strong society and the main ground for restoring the authentic culture and raising spiritually powerful generations. Such familial definition of women's citizenship continues to be the target of feminist criticisms about the gender agenda of the party. The intensification of a new form of patriarchy is a serious concern raised by various scholars. ${ }^{25}$ Such intensification takes place through the active involvement of women in the governing party as well as high levels of support from women voters.

If the sources of high levels of women's support for the AKP become the subject of analysis to discuss the possibilities of furthering women's liberation in Turkey, a thorough reading of all available constructions of 'new' women citizenship in Turkey and their interrelated characteristics is necessary. Sirman argues that it is the differences and contradictions among the competing projects and their sets of values which 'produces the energy that propels the story forward ... where the values are redefined, negotiated, managed and grounded arriving momentarily at a resolution. ${ }^{26}$ The adventure of the heroine takes place among different sets of historical, social or moral values and reaches a resolution. How different formulations of feminine subjectivity are constructed through delegitimizing, negating and disavowing other subjectivities within the narrations of competing actors, hence their serving as the constitutive other of a given subjectivity, becomes subject of analysis in this approach. Thus, how different formulations of the 'new' womanhood in the reformulations of collective identity throughout constitutional debates refer to each other, how the depictions of daughterhood in the CHP's programme and sisterhood in the HDP's programme are negated to formulate the motherhood in the AKP's programme and vice versa, the negation and disavowal of the AKP's construction of motherhood as the 'constitutive other' of other projects might have important contributions to the analysis of renegotiations of femininity throughout the constitutional debates in today's Turkey.

\footnotetext{
${ }^{21}$ Yücesan-Özdemir, Gamze, ed., Silent Violence: Neoliberalism, Islamist Politics and the AKP Years in Turkey (Ottawa: Red Quill Books, 2012).

${ }^{22}$ Gamze Cavdar, 'Islamist Moderation and The Resilience of Gender: Turkey's Persistent Paradox', Totalitarian Movements and Political Religions 11, no. 3-4 (2010): 341-57.

${ }^{23}$ Cosar and Yegenoglu, 'New Grounds for Patriarchy in Turkey?', 567.

${ }^{24}$ Gulbanu Altunok, 'Neo-conservatism, Sovereign Power and Bio-power: Female Subjectivity in Contemporary Turkey', Research and Policy on Turkey 1, no. 2 (2016): 132-46.

${ }^{25}$ See for example Ayhan Kaya, 'Islamisation of Turkey Under The AKP Rule: Empowering Family, Faith and Charity', South European Society and Politics 20, no. 1 (2015): 47-69; Cosar and Yegenoglu, 'New Grounds for Patriarchy in Turkey?', 555-573; Canan Aslan Akman, 'Islamic Women's Ordeal with the New Face (S) of Patriarchy in Power: Divergence or Convergence over Expanding Women's Citizenship', in Gendered identities: Criticizing Patriarchy In Turkey, ed. Yasin Ozgur Donmez and Fazilet Ahu Ozmen (Plymouth: Lexington Books, 2013), 113-45.

${ }^{26}$ Sirman, 'Writing the Usual Love Story', 252.
} 
The campaign material of the 2014 presidential elections in Turkey provides an important resource to analyse and discuss representative claims about women and different depictions of womanhood in the candidates' agenda. Representative claims about women means defining women as a distinct group within a given constituency and using discourses of history, national identity, law, rights and freedoms, economy, ethics, culture or religion to legitimize that definition. ${ }^{27}$ For the purposes of analysing these claims, in this study, the candidates' campaign speeches, interviews and election statements within the legally allowed dates of election campaign, from 11 July to 9 August, were used. First, the transcriptions of all candidates' election bulletin presentations were collected. Secondly, the candidates' TV and newspaper interviews that are available online have been collected and transcribed when necessary. Among the three candidates, Erdogan appeared in printed and visual media that are known to have close connections with the government. Ihsanoglu and Demirtas appeared on TV channels and newspapers from a more diverse political spectrum. Ihsanoglu and Demirtas also participated in meetings particularly organized for women by a wellknown women's civil society organization working for increased political representation of women, the Association for Support of Women Candidates (Kadın Adaylari Destekleme Dernegi, KADER). ${ }^{28}$ Demirtas's campaign also involved a meeting particularly with women at a big, well-known public park in Istanbul. Erdogan's meeting with women took the form of gatherings with a group of professional women for a TV channel in a question and answer format. All of these interviews were collected and included in the analysis. Thirdly, the rallies organized by the candidates were analysed. Due to the official time restraints for campaigns as well as financial limitations, rallies became a secondary strategy of campaigning compared to the use of public and social media. Still, for this study, two rallies for each candidate were selected, transcribed and included in the analysed material. The data have been analysed in terms of the candidates' call to the female constituency to offer new gendered experiences of citizenship such as serving for the well-being of their country as good mothers, as appeased daughters or as those who have feminist consciousness and desire for women's solidarity and sisterhood.

\section{Findings}

\section{Erdogan: pious women, 'fitrat' and strong presidency}

Throughout his election campaign, Erdogan highlights the discriminatory nature of the Republican regime embedded in a strict practice of secularism. The authoritarian character of the Turkish republican regime is an important theme in his campaign, during which he presents himself as the leader who replaced the rule of the secular elite with what he calls the rule of masses. ${ }^{29}$ Erdogan argues that pious individuals and symbols of religion had been

\footnotetext{
${ }^{27} J$ udith Squires, 'The Constitutive Representation of Gender: Extra-Parliamentary Re-Presentations of Gender Relations', Representation 44, no. 2 (2008): 187-204; Karen Celis, Sarah Childs, Johanna Kantola, and Mona Lena Krook, 'Constituting Women's Interests Through Representative Claims', Politics \& Gender 10, no. 2 (2014): 149-74; Eline Severs, 'Representation as Claims-Making. Quid Responsiveness?', Representation 46, no. 4 (2010): 411-23.

${ }^{28}$ Erdogan's not participating in KADER's meetings is important in terms of revealing his approach to the issue of women's equality. KADER is a well-known NGO working for women's representation in the political arena as equals of men. Erdogan on the other hand had stressed his critical approach to such stress on equality on various grounds by saying that women and men cannot be equal since they are naturally different and complement each other.

${ }^{29}$ Recep Tayyip Erdogan, 'Hatay Meeting' (Hatay Mitingi) (Itfaiye Square, Hatay, July 20, 2014).
} 
kept from public offices, universities and the mainstream economy due to the rigid practice of secularism. He takes pride in successfully defending the rights of pious Muslim citizens who were 'pushed to the margins' and putting an end to their alienation. As an outcome of what he calls the democratic opening under the AKP governments, Erdogan announces that he has reversed the understanding of 'prioritizing state over society' and forced an inevitable change in the established tradition of governance based on bans and intimidation. ${ }^{30}$

\section{Erdogan's historical revisionism and call for women's mobilization}

Erdogan's criticism of the Republican status quo extends to his diagnosis of women's status and place in Turkey. He argues that the main challenge pious women face under the Republic is their exclusion from the public sphere. In his criticism, Erdogan refers particularly to the headscarf ban that used to be enforced on public employees, university students and parliamentarians. Erdogan maintains that as a result of these strict bans, headscarved women 'were not seen anywhere in public and were rendered invisible..' The ban deprived a significant part of the female population of their social, economic and citizenship rights. ${ }^{32}$ Therefore, 'pious women' as a distinct interest group are constructed through references to their historical exclusion and subordination.

The protection of women's freedom of faith in the public sphere and the reversal of the damage the Republic inflicted on women's spirituality and thus on the whole society is the core of Erdogan's representative claim about women's interests. Family is the main area where this restoration is to be initiated in accordance with this claim. Erdogan has been emphasizing that'family is not a technical or formal structure for the conservative democrats, but rather a spiritual thing and the foundation of society, the dissolution of which ends up with the corrosion and degeneration of both individual and society.'.33 The president, the argument follows, oversees ending pious women's exclusion and bringing them into the public sphere as an ardent initiator of family-related policies. Erdogan mentions the progressive removal of headscarf bans during his time as prime minister to establish himself as the capable and strong-minded representative of pious women.

\section{New constitution and women}

Erdogan argues that when political institutions seek to refashion the society through discourses of modernization, enlightenment and Westernization, this leads to domination by the elite. He does not favour the elite domination and argues that it is necessary for the state to represent the masses and to serve their demands. In this formula, it is the role of political representatives to identify the authentic cultural and historical core of society. The new social contract Erdogan advocates is defined as common people's reclamation of the political power from the secular elite who, according to Erdogan, have far too long dominated social,

\footnotetext{
${ }^{30}$ Recep Tayyip Erdogan, 'Presentation of Election Vision Document' (Secim Vizyon Belgesi Sunumu), (Halic Congress Center, Istanbul, July 11, 2014).

${ }^{31}$ Recep Tayyip Erdogan, moderated by Hulya Seloni, Women Asking Erdogan (Kadinlar Erdogan'a Soruyor) Kanal7, August 8, 2014.

${ }^{32}$ The abolishment of the ban became a matter of controversy during the time of constitutional battles between the AKP and the secular establishment. The decision reached in the parliament to remove the ban was taken up to the Constitutional Court by some of the opposition parties on the grounds that it violated the secularism principle laid out in the constitution. The ban was finally removed in 2013.

${ }^{33}$ Zafer Yilmaz, "'Strengthening the Family" Policies in Turkey: Managing the Social Question and Armouring ConservativeNeoliberal Populism', Turkish Studies 16, no. 3 (2015): 378-9.
} 
political and economic spheres in Turkey. According to this argument, while pious headscarved women have suffered from this elite domination due to their exclusion from public institutions, other women who have not been provided with the services to actualize their 'true', natural womanhood, which is defined as motherhood, are also the victims of this period that he calls as the rule of the secular elite.

Thus, in Erdogan's rhetoric, women are attributed a distinct role in this process of reclaiming the political power from the secular elite. An effective representation of women means developing women's capacities as good mothers, since strong family is the prerequisite for a strong society. Erdogan redefines women within the context of family by stressing their importance for the family structure and for the society as its extension. His gender rhetoric and his redefinition of women's status under the new contract are not based on a pursuit of equal rights and opportunities for both sexes. Women are entitled to certain rights but it is not necessarily because they are equal citizens and human beings. They should have rights because they are the building blocks of the family, and family unity is essential for a healthy society, which will re-establish the moral and cultural values destroyed by the authoritarian secularist project. Women as mothers have a moral and historical responsibility to achieve this end. In Erdogan's rhetoric, their motherly nature should be cherished and supported through the social benefits the state offers.

Under this new arrangement, women's active participation in social life is acknowledged. Women are to be supported through proper education and through some degree of empowerment. Erdogan singles out education in his reformulation of gender. Female education is important because its absence results in marriages and family structures that are not sustainable. Erdogan proposes special marriage courses, which should ideally be introduced during the secondary school and high school years. An understanding of marriage, in Erdogan's words, 'should not be something acquired on the streets.' ${ }^{34}$ He emphasizes that Islam considers family as the founding block of the society, and the Turkish society 'as you know is $99 \%$ Muslim. ${ }^{35}$ Consequently, in this representative claim, women from this $99 \%$ of the population become symbols of the masses' suffering at the hands of authoritarianism. Bringing the family back in, on the other hand, represents the triumph of the masses.

\section{Role of the president}

During his campaign, Erdogan underlines his intention of not following the lead of the presidents preceding him and promises to be a president who would be involved in everyday political agendas and executive governmental activities. ${ }^{36}$ For Erdogan, this kind of presidency that is held by a popularly elected president is a sign of the dissolution of state's alienation from the people. In a presidential system, Erdogan will stand as the guard of all that belongs to the people, including the social and cultural rights of pious women. That the president is elected by universal vote for the first time only adds to Erdogan's emphasis

\footnotetext{
${ }^{34}$ Erdogan, Women Asking Erdogan.

${ }^{35}$ Ibid.

${ }^{36}$ Recep Tayyip Erdogan, interview by Mehmet Acet, Port and Starboard: Prime Minister Recep Tayyip Erdogan Special (İskele Sancak: Basbakan Recep Tayyip Erdogan Ozel Programi), UlkeTV, July 27, 2014. Erdogan kept his promise. Before the constitutional referendum on executive presidency was held on 16 April 2017, Erdogan's term in office as president was characterized by his exerting a great deal of influence over government affairs, breaching the constitutional requirements that define a limited role for the president. It is highly probable that this de facto presidential system will now be formalized in Turkey. Although the official results of the referendum have not been declared while this article was being prepared for publication, a slim majority of the electorate voted in favour of the constitutional amendments for establishing an executive presidential system according to unofficial results.
} 
on the need to transform the government model. The Turkish president's active role and representative authority, as formulated by Erdogan, is constructed through a narration of the past as a conflict-based relation between secular women alienated from their authentic culture and pious women who are the carriers of the culture to the future. Therefore, the president becomes the initiator and an active overseer of policies developed for women to allow them to live in accordance with their motherly genesis (fitrat) while simultaneously protecting women from their historical suppressors. It is in this sense that Erdogan's formulation of women's needs and interests is an important point of reference through which he legitimizes his claim about why a presidential system will serve the best interests of women.

\section{Ihsanoglu: re(e)valuation of the republican tradition and the path to women's emancipation}

During the presidential election, the Republican People's Party (Cumhuriyet Halk Partisi, CHP), together with one of the other major opposition parties, the Nationalist Action Party (Milliyetci Hareket Partisi, MHP), nominated a candidate, Ekmeleddin Ihsanoglu, whom they thought had an appeal for both the religious and the secular electorate. Ihsanoglu was supported by an additional 12 extra-parliamentary political parties 'ranging from left-of-centre to the far right on the Turkish ideological spectrum.37

Ihsanoglu is an important figure in Turkish academic circles and he has published extensively on the history of Islam. ${ }^{38}$ As the secretary general of the Organization of Islamic Cooperation in 2004-2014, Ihsanoglu is also well known in global diplomatic circles. His nomination had 'impeccable Islamic credentials' and can be seen as an attempt by the CHP to appeal to a more religious electorate than its usual support base. ${ }^{39}$ In contrast to Erdogan, Ihsanoglu has as much appreciation for the Republican history as for the Ottoman legacy. He also strikes a chord with the nationalist electorate through family ties. Ihsanoglu's father was Mehmet Akif Ersoy's best friend. Ersoy (1873-1936) penned the lyrics for the Turkish national anthem and remains a widely respected figure among the Turkish nationalists who are disillusioned by Erdogan's critique of Republican nationalism. Ihsanoglu's nomination was an attempt to subvert Erdogan's reading of Turkish history as an ongoing conflict between the secular elite and the pious Muslim masses.

\section{Ihsanoglu's historical revisionism and call for women's mobilization}

Ihsanoglu is the only candidate openly favourable to the Republican heritage. He argues that he will not be the first president to 'rule this state under parliamentary regime'. ${ }^{40} \mathrm{He}$ points at the Ottoman state in pursuit of further justification for the current system and argues that even 'sultans shared political responsibility with ministers'.11 Thus the current regime, which is based on a separation of powers, is a continuation of the Ottoman state tradition and the fact that it is still standing is a proof that it has survived various tests of legitimacy. Turkey suffered from three direct $(1960,1971,1980)$ and one indirect (1997) coups

\footnotetext{
${ }^{37}$ Ersin Kalaycioglu, 'Turkish Popular Presidential Elections: Deepening Legitimacy Issues and Looming Regime Change', South European Society and Politics 20, no. 2 (2015): 161.

${ }^{38} \mathrm{Ihsanoglu}$ was elected to the parliament on the MHP ticket in the 2015 elections.

${ }^{39}$ Ioannis N. Grigoriadis, 'The Turkish Presidential Elections of 10 August 2014', Mediterranean Politics 20, no. 1 (2015): 108.

${ }^{40}$ Ekmeleddin Ihsanoglu, 'Election Bulletin' (Seçim Bildirgesi) (Ciragan Palace, Istanbul, July 10, 2014).

${ }^{41}$ Ibid.
} 
d'état, ${ }^{42}$ which Ihsanoglu defines as the most disturbing moments in the history of the Republic. However, rather than referring to these coups as the proofs of state repression Ihsanoglu has been arguing that focusing on the negative aspects should be avoided and the merits of the Republic should be acknowledged. Ihsanoglu's conservatism, as he describes, is based on protecting the republican values and institutions. ${ }^{43}$

Ihsanoglu also argues that there is not a considerable demand for changing the political system in favour of presidentialism. If the AKP refers to its majority position in the parliament as the proof of such a demand, Ihsanoglu argues that his nomination by a coalition of the main opposition parties shows an opposite trend for maintaining the republican tradition. Therefore, Ihsanoglu's representative authority is constructed through references to a state tradition that is to be conserved with certain alterations so that the political status quo will no longer provide a basis to legitimize coups or the presidential model proposed by Erdogan.

In Ihsanoglu's political discourse, women are the victims of coups. Like Erdogan, Ihsanoglu also places the headscarf issue at the centre of his gender rhetoric. He believes that the most recent coup in 1997 against the rising popularity of Islamist factions and the Islamist Welfare Party (Refah Partisi, RP) ended up further empowering political Islam. In 1997 the National Security Council declared the headscarf as one of the indicators of an Islamic threat and 'called for the enforcement of a ban on the headscarf in all public places, including classrooms, universities, and public offices. ${ }^{4}$

Ihsanoglu argues that he is against limitations placed on the headscarf by the state and the securitization of the issue in the periods of coup d'état. ${ }^{45}$ Thus, similar to Erdogan, the headscarf controversy and the freedoms and rights of pious women constitute the bulk of Ihsanoglu's representative claim about women. However, the depiction of the sources of women's problems is different. Rather than relating the issue to a strict depiction of secularism since the foundation of the Republic, he locates the controversy within the political context of the 1980s and 1990s and the securitization of the issue by the secular establishment.

Ihsanoglu argues that it is in the best interest of pious and secular women in Turkey to resolve the misinterpretation of the Republican heritage and of Islam as patriarchal and assimilatory against women. In his words, 'We have polarized our daughters through this headscarf controversy' ${ }^{\prime 6}$ and the children of Turkey should no longer be polarized on any issue to gain political benefit. Thus, Ihsanoglu depicts himself as the president who can put an end to the historical controversy between secular and Islamist worldviews.

\section{New constitution and women}

Throughout his campaign, Ihsanoglu stresses the need for reforming women's standing in the political and social fora. The way to achieve this is to accommodate previously alienated headscarved women in social and political life while maintaining the benefits of the secular

\footnotetext{
${ }^{42}$ Aylin Güney and Petek Karatekelioglu, 'Turkey's EU Candidacy and Civil-Military Relations: Challenges and Prospects', Armed Forces \& Society 31, no. 3 (2005): 441.

${ }^{43}$ Ekmeleddin Ihsanoglu, 'Kugulu Park Speech' (Kugulu Park Konusmasi) (Kugulu Park, Ankara, August 4, 2014).

${ }^{44} \mathrm{Alev}$ Cinar, 'Subversion and Subjugation in The Public Sphere: Secularism and The Islamic Headscarf', Signs 33, no. 4 (2008): 891.

${ }^{45}$ Ekmeleddin Ihsanoglu, 'Election Bulletin'.

${ }^{46}$ Ekmeleddin Ihsanoglu, 'Hatay Press Conference' (Hatay Basin Toplantisi) (Hatay Metropolitan Municipality Social Facilities Center, August 2, 2014).
} 
Republican regime. Ihsanoglu argues that these two groups of women have been viewing each other as an existential threat. To put an end to this enmity, headscarved women and secular women will have to get rid of their biases vis-à-vis each other. The secular women will have to be more respectful of the freedom of faith while headscarved women will have to approach the Republican values from a more positive perspective. For Ihsanoglu, both the history of Islam and the Republic provide good cases for gender equality and show that the current problems faced by women are not the outcomes of either tradition. Thus, the arbitrary conflict between the supporters of Republican secular values for women's emancipation and advocates of religious freedoms and rights is a major misunderstanding of Islam as a patriarchal and suppressive religion. It is this misunderstanding that Ihsanoglu sets out to resolve. The president's source of authority emerges from his role as a mediator between these two groups, who see each other as the obstacle in the way of women's emancipation.

Ihsanoglu's suggestion is to re-establish people's trust in the core values of the Republic and to guarantee the citizens' right to live according to their beliefs while passing it to the next generations. Ihsanoglu acknowledges that 'women have a secondary status in the Islamic world' ${ }^{47}$ However, he attributes this status to political reasons rather than religious ones and argues that during the Prophet Mohammed's time women were'active in warfare and economy,',8 thus Islam does not dictate the subordination of women.

Ihsanoglu highlights the Republic's efforts, too. First, with the modernization reforms in the late Ottoman period, women entered universities. Then, under the Republic they became 'ministers, police officers or pilots'. ${ }^{99}$ Thus, he argues, when the merits of Islam and the Republican modernization are acknowledged by people, polarization can become a thing of the past. Only then will the debate on women's rights be much better qualified for addressing policy issues about women's emancipation, and trust in political institutions will be restored. Women, the other half of men as Ihsanoglu puts it, contribute to the prosperity of first and foremost their own families and secondly to the nation's wellbeing. Once a new political imperative that would unite women is accomplished, politics can finally become a venue where 'real' problems of women become the subject of political debate. Ihsanoglu defines these real problems in terms of the social, cultural and economic subordination of women and the notorious domestic violence issues. Turkish women face serious problems, he says, including 'honour' killings, violence against women, enforced and under-age marriages and limited participation in economic and political life. ${ }^{50}$ Although these problems had been problematized by feminist organizations as reflections of the patriarchal logic of the state, disallowing their entering the criminal law as gender-based crimes, in Ihsanoglu's representative claims, such a responsibility of the state in these crimes is totally neglected. On the contrary, they are depicted as sociocultural problems that are to be fixed by the state and his representative authority as president is constructed as deriving from the role of resolving these problems and serving women's common interests.

\footnotetext{
${ }^{47}$ Ekmeleddin Ihsanoglu, moderated by Ahu Ozyurt, 'Association for the Support and Training of Women Candidates (KADER) Meetings with the Presidential Candidates (Kadın Adaylari Destekleme Dernegi (KADER) Cumhurbaskani Adaylari Ile Bulusmalar)' (Dedeman Hotel, Istanbul, July 17, 2014).

${ }^{48}$ Ekmeleddin Ihsanoglu, interview by Taha Akyol, The Truth of the Matter (Egrisi Dogrusu), CnnTurk, July 3, 2014.

${ }^{49}$ Ihsanoglu, 'Election Bulletin'.

${ }^{50}$ Ihsanoglu, 'Election Bulletin'.
} 


\section{Role of the president}

Ihsanoglu argues that as the head of state, the president oversees the unity of the state and the republic, the harmonious functioning of state institutions and the implementation of the constitution. ${ }^{51}$ Ihsanoglu argues that presidents are by definition impartial. The president should maintain an equal distance to all political parties and ideologies. In other words, he should act like a'head of family' that brings the nation all together. ${ }^{52}$ Presidents or presidential candidates are not in a position to make policy promises to the electorate. At his/her most active, the president might introduce some policy recommendations to the government or activate institutions such as the State Auditing Board. Even as commander in chief, the president is only a reflection of parliament's powers and $s / h e$ is exercising this role on behalf of the parliament. ${ }^{53}$

For Ihsanoglu, this limited scope of the presidency is a historical given. It goes beyond the Republic as he argues that the separation of powers was introduced with the Ottoman Empire's Second Constitutional Era (1908-1922) when the sultan transferred a substantial part of his powers to the prime minister while maintaining his ceremonial duties. Ihsanoglu argues that contrary to Erdogan's claims, Ataturk continued the Ottoman tradition rather than demolishing it. ${ }^{54}$ Ihsanoglu's support for the parliamentary model vis-à-vis the presidential one is also accompanied by his strong preference for a unitary form of government as opposed to a decentralized model proposed by Demirtas. Thus, Ihsanoglu finds his opponents' political models destructive to a long-standing state tradition.

From the gender perspective, Ihsanoglu has been bringing up the projects he initiated as the Secretary General of the Organization of Islamic Cooperation. He promises to develop gender equality initiatives also as president. ${ }^{55}$ The initiatives he launched as the Secretary General on gender issues were also referred to as a symbol of his struggle against the Eurocentric view about Islam's incompatibility with gender equality. Ihsanoglu promises to form a political platform to facilitate dialogue between various women's organizations and female representatives from different segments of the society. The president's role is to develop ties of collective trust and solidarity among the daughters of the nation, which is defined as a family. Although women's organizations have already been in dialogue to make the state responsible for taking the necessary measures to resolve gender-based inequalities since the 1980s, Ihsanoglu's making no reference to their legacy and framing their dialogue as that of the cooperation of 'daughters' under the tutelage of the central 'father' can be read as a distinct type of state feminism.

\footnotetext{
${ }^{51}$ Ekmeleddin Ihsanoglu, 'Hatay Press Conference'.

${ }^{52}$ Ihsanoglu,'Hatay Press Conference', Ekmeleddin Ihsanoglu 'Who Can Intervene in the Private Lives of Adults?' (Resit Insanlarin Ozel Hayatina Mudahale Kimin Haddine?) Interview by Ayse Arman, Hurriyet, July 14, 2014, http://www.hurriyet.com.tr/ kelebek/hayat/26791382.asp (accessed July 12, 2015). 'Head of family' which is 'aile reisi' in Turkish actually refers to the 'husband' within the family. This was mentioned as such in the Civil Code until 2002 amendment. After this amendment, the'head of the family' expression was replaced by the family's being defined as an entity that is based on equality between husband and wife. Ihsanoglu's using this expression to refer to himself as the head of the national family can be read in terms of the limited nature of his approach to gender-equal state and society.

${ }^{53}$ Ihsanoglu, 'Hatay Press Conference'.

${ }^{54}$ Ihsanoglu, 'Hatay Press Conference', Ihsanoglu, 'Kugulu Park Speech', Ekmeleddin Ihsanoglu, 'A Question to Ekmeleddin Ihsanoglu about Erdogan that will be Talked A Lot' (Ekmeleddin Ihsanoglu'na Cok Konusulacak Erdogan Sorusu). Interview by Nuriye Akman, Samanyolu Haber, July 17, 2014, http://www.samanyoluhaber.com/politika/Ekmeleddin-Ihsanoglunacok-konusulacak-Erdogan-sorusu/1056512/ (accessed July 12, 2015).

${ }^{55}$ Ihsanoglu, KADER Meetings with the Presidential Candidates.
} 
Ihsanoglu's support for gender equality is critical for two reasons. First, it serves to support his own claim as a follower of the women's emancipation project that started during the late Ottoman period. Second, despite emphasizing women's role as mothers and himself as the father of the national family, Ihsanoglu's way of filling in these roles differs from that of Erdogan. Mothers are called for serving the well-being of the national family rather than becoming the main actors for moral restoration. The role of the president is to prevent polarization among them and make the presidency meeting ground for women from all segments and views.56 Ihsanoglu argues that maintaining the distance between state institutions and everyday politics in a parliamentary model is beneficial to fulfil this purpose. This distance serves the interests of disempowered women who, due to their lack of social and economic resources, can be easily manipulated by the power-seeking political elite.

\section{Demirtas's 'new society project' and criticism of the state feminism}

Selahattin Demirtas is a Kurdish politician, whose political career started in the early 1990s when an extended state of emergency was declared in the southeast of the country due to the escalating Kurdish insurgence. Demirtas became a member of the parliament in 2007. After consecutive bans on several Kurdish parties by the Constitutional Court, the Peoples' Democratic Party (Halkların Demokratik Partisi, HDP), which is currently co-chaired by Demirtas, became the most recent Kurdish party, established in 2012. While seeking the support of the non-Kurdish electorate throughout the election campaign, the strong presence of women within the HDP has been one of the potentially attractive characteristics of the party for this non-Kurdish electorate.

The HDP is the only party that applies a functioning $50 \%$ quota for women. The HDP also practises a co-representative partner system, which requires that all critical positions such as the office of mayor or political party chair are held by both a male and a female party member. The woman question is, thus, a major part of the radical democracy project promoted by the movement. High numbers of women participate in HDP-affiliated civil society activities and elected representatives of the party present a distinct model for building a gender-equal society.

\section{Demirtas's historical revisionism and call for women's mobilization}

As indicated by Grigoriadis, during his election campaign, Demirtas 'abstained from exclusively focusing on the Kurdish issue. ... Instead, he raised - alongside the Kurdish question - a set of political issues linked to democratic consolidation, human rights and the rule of law.57 As part of this emphasis on the necessity for democratic consolidation, Demirtas argues that the current regime in Turkey is anti-democratic, subordinating and exclusionary. The reason is the historical trajectory of nation-state formation in a multi-ethnic and multi-cultural context. The centralized nation-state model and its assimilative and suppressive historical legacy are where Demirtas traces the sources of the anti-democratic and exclusionary nature of the current regime. He says that the system always produces a clash between the state and society mainly because all definitions of a single nation, single race

${ }^{56}$ Ibid.

${ }^{57}$ Grigoriadis, 'The Turkish Presidential Elections of 10 August 2014', 109. 
or a single religious sect that unites the citizens are based on false and unilateral readings of history. ${ }^{58} \mathrm{He}$ argues that unitary claims about the nation's interests exclude, ignore, delegitimize and criminalize demands for political pluralism and representation.

Demirtas calls for radical democratic alterations to the current political model to resolve the problems of representation. Such problems mainly consist of subordination and criminalization of the political activities of religious, ethnic, cultural and linguistic minorities and socially and economically disadvantaged groups in the name of protecting the nation's integrity. His 'new society project' claims to restructure the state in a way that will enable societal and political pluralism rather than imposing a unitarian (tekçi) logic over this multicultural setting in the name of maintaining the national unity. He prioritizes the state's responsibility in introducing political measures that will allow citizens to influence decision-making processes from 'below'.

From Demirtas's perspective, the main challenge in women's representation in Turkey is the instrumental understanding of feminism that incorporates women into the formation and reproduction of national unity. He questions the official myth of the Republic as the saviour of women from backward feudal and paternalist cultural traditions. Demirtas argues that different versions of this myth serve for inventing the category of 'Turkish women' who demand to be saved and protected by the state. Such a myth also delegitimizes demands for cultural rights since these rights will reverse women's emancipation and make them victims of 'backward' cultures again. In this sense, Demirtas challenges the state feminism tradition in Turkey and the state monopoly on defining what can be politicized as women's interests.

Therefore, within his representative claims, women are constructed as a group who have had a different status from men throughout modern Turkish history in the sense that they had been expected to serve and obey the state depicted as their emancipator. He argues that Erdogan carried on this legacy rather than bringing a change. Demirtas calls on the female constituency to stop being functional servants of the state and start demanding services, social and cultural rights as equal members of the political community irrespective of their religious, ethnic, cultural or social background. He maintains that each female vote for him will mean the presidency no longer belongs to a representative with absolute authority who exploits women's desire for emancipation with an authoritarian logic. ${ }^{59}$

Rather than constant expressions of gratitude to their emancipator, the real indicator of equal citizenship for women will be putting an end to the sense of gratitude as the main bond between women and the state. The president's authority derives from his moral and political obligation to alter the relationship between women and the state. The role of the president as constructed by Demirtas is to initiate the necessary democratic reforms for this purpose.

\section{New constitution and women}

Demirtas has argued that the AKP's electoral success is a result of the support of those who were critical of the civil war, state violence, injustice and corruption. There were several groups who suffered from these conditions. The AKP received the support of these ideologically diverse groups and went on to brand its electoral success as the success of political Islam.

\footnotetext{
${ }^{58}$ Selahattin Demirtas, 'Macka Meeting with Women' (Macka Park, Istanbul, July 30, 2014).

${ }^{59}$ Demirtas, 'Macka Meeting with Women'.
} 
To raise against the AKP's authoritarian agenda, Demirtas has asked for the votes of those who previously supported the AKP: 'you have resisted military interventions, tortures, exploitations ${ }^{\prime 60}$ and 'it is this legacy of resistance that is being suppressed by another authoritarian group that claims itself as the only victim of militarism in this country'.61 He argues that radical democracy can serve the interests of various groups, such as Muslims, ethnic and religious minorities, women, workers and LGBTs, best. Without radical democracy, those who claim to represent the interest of the state will continue to label those who demand inclusion and recognition as illegitimate political actors seeking to dissolve the integrity of the nation. Therefore, without a systemic change, according to Demirtas, the state will continue to be authoritarian and paternalistic unless equal representation of all cultural, religious and gender identities as well as socially and economically marginalized groups is guaranteed. Radical democracy is defined as the only way to replace unitary definitions of Turkish society with cultural, ethnic and political pluralism. It is this call for radical democracy Demirtas refers to as the 'new society' project as opposed to Erdogan's'new Turkey' project. He argues that such a 'new society', which will also be characterized by the end of violence and discrimination against women, can only be organized and maintained under the leadership of women themselves. ${ }^{62}$

In terms of women's representation, Demirtas argues that the actual challenge is not about promoting women's equal presence in political offices, which are laden with patriarchy and militarism. The challenge is to work for women becoming 'the voice of those suppressed and patronized within this masculine game of authority'.63 Without introducing the mechanisms to discredit the suppressive and paternal state authority, women's presence in politics will not necessarily be progressive in terms of policies women might produce. Demirtas gives the example of Tansu Ciller's term as prime minister (1993-1996), a period known for an extensive exercise of state violence and repression. He stresses that burning down of Kurdish villages and unsolved crimes of the state's contra-guerrilla establishments mostly took place during her government. 'She adopted the patriarchal and the militaristic mentality we criticize. ${ }^{64}$ Radical democracy is what Demirtas offers as the only way to dissolve this patriarchal logic that is embedded within the patronizing paternal central authority.

\section{Role of the president}

Demirtas is in favour of empowering the elected local representative offices while simultaneously decreasing the authority of the president and the parliament. 'Real democracy in Turkey cannot be established with weak local representative offices that are accountable to the central government rather than to their own local constituency. ${ }^{\prime 65}$ This change will accomplish the inclusion of different groups in the political decision-making process and enhance the mechanisms of accountability and transparency.

Strengthening the role of president, as suggested by Erdogan, means replacing one authoritarian institution with another and is anything but democratic, according to Demirtas.

\footnotetext{
${ }^{60}$ lbid.

${ }^{61}$ Selahattin Demirtas, moderated by Sirin Payzin, 'Association for the Support and Training of Women Candidates (KADER) Meetings with the Presidential Candidates (Kadın Adaylari Destekleme Dernegi (KADER) Cumhurbaskani Adaylari lle Bulusmalar)' (Dedeman Hotel, Istanbul, July 25, 2014).

${ }^{62}$ Selahattin Demirtas, 'Road Map Speech' (Sisli City Culture Center, Istanbul, July 15, 2014).

${ }^{63}$ Demirtas, KADER Meetings with the Presidential Candidates.

${ }^{64}$ Selahattin Demirtas, 'Road Map Speech'.

${ }^{65}$ Demirtas, What's Going On: Presidential Election Special.
} 
'Erdogan represents a common idea in Turkey that the antidote to military guardianship is a strong political leader. ${ }^{\prime 6}$ However, Demirtas argues, the real end to the guardianship and an exercise of true democracy will only arrive when political authority is spread to the society as much as possible. Thus, in Demirtas's formulation, the role of president should be to motivate the parliament and all political actors as well as stakeholders to initiate a constitutional change to establish a radical democratic system. Both models, where the president represents the common good in the case of Ihsanoglu and where the president is the voice of people in the case of Erdogan, are assimilative models of governance that limit the political participation of citizens.

Demirtas argues that initiating the change towards a more decentralized model will be the most important contribution of the president to gender equality. The argument follows that state feminism, which has defined women as secular mothers of the nation state in the Republican period, is now being maintained by policies that define them as conservative mothers. In both cases, the implementers of these policies succeeded in recruiting numerous women to their cause by intimidating them about alternative scenarios. These scenarios, as indicated by Demirtas, were either the threat of Islam, which will subordinate women in the absence of state oversight, or a Western-oriented secular elite, who will discriminate against Muslim women and take away their freedom of belief in the name of modernization. Demirtas promises to end such politics of fear.

\section{Conclusion}

The 2014 Turkish presidential elections were of historical importance since it was the first time the president was elected by a universal vote. The campaign turned into a competition about which government model Turkey should adopt in the future. Ihsanoglu offered revisions to the parliamentary system. Erdogan proposed replacing the parliamentary system with a presidential regime and Demirtas offered enhanced powers for local governments at the expense of the central parliament. Women's needs and problems were at the centre of historical narrations and policy formulations through which the necessity and possible contributions of these proposed systems are legitimized. Each presidential candidate, based on their readings of recent Turkish political history, had his own authentic claims concerning the representation of women's interests.

The consensus on the necessity to reconsider the status of women in the country in the context of the new constitution-making process also brought deep fractures and disagreements. These fractures emerged mainly from the question of which women should be prioritized in their representative claims. In the case of Erdogan, it is the pious women, who had suffered the most under the secular founding ideology of the Republic. In Ihsanoglu's campaign, it is the women who suffer from domestic violence and early-age marriages, which cannot be resolved due to polarization between the secular and the pious women of the country. Demirtas refers to all women as well as LGBTs as the victims, since the militaristic and unionist ideology of the central state only served in the interest of secular nationalist men in the past and is serving for Islamist nationalist men today. Attempts were made by all three candidates to mobilize women's support for their proposed regimes through

${ }^{66}$ Demirtas, What's Going On: Presidential Election Special. 
narrations of the pain that the women have suffered under the current establishment. These women were invited to identify themselves with their pains as mothers, daughters or sisters, which will provide them a new sense of selfhood and a historical responsibility as women. This is in line with what Sirman defines as the narrative formulation of a 'new' femininity through 'painful process of negotiation that women as subjects have to enter into to gain respect, stability and happiness'.67

In both Erdogan's and Ihsanoglu's rhetoric, the legitimacy of the president derives from being the protector and guarantor of this new womanhood. This experience is rewarded by a respectful position which the state will be representative of as the best, true form of femininity that necessitates no further emancipation. The value and respectfulness of all other types of womanhood are to be measured with reference to this idealized and respected femininity. Within Erdogan's representative claims, women who naturalize their motherhood as their prior sense of self are provided with a moral superiority from elitist women of the CHP and feminist women of the HDP, who are alienated from their true selfhood. Ihsanoglu's project of appeasing the daughters of the country is an attempt to reclaim the respectfulness of secular women in the eyes of their conservative or Islamic sisters who support the AKP. He defines both groups as emancipated by the Ottoman regime, where the real common roots of their equal rights can be traced. Thus, they are both acknowledged as the daughters of the same father state that served for their benefit and the parliamentary regime represents this historical heritage, as opposed to presidentialism of Erdogan which is disrespectful of it.

Demirtas is the only candidate who problematizes how the state's control on women's agency is maintained through its being defined as the saviour and protector. Thus, his main contribution is stressing how this protective role delegitimizes any attempts to seek further rights for women as well as for LGBTs who seek equal citizenship for gender identities that do not fit in the officially acknowledged one as the true, respectful forms of femininity. Demirtas criticizes state feminism for aiming to construct strong ties of loyalty to the state authority in the social imaginary of women as their saviour and liberator. It is this imaginary that constructs them as respectful women of the country due to bringing resolution to women's pain. Demirtas attempts to destabilize this imaginary through depictions of how the central authority has made women complicit in its authoritarian and militaristic logic throughout its history. The most typical example of such patriarchal collaboration of women with the militarist ideology of the state has been depicted as Tansu Ciller. He presents his radical democracy project as a call for the women of the country to dethrone this suppressive and authoritarian masculine and together building a'new society' as sisters without having to declare any sense of loyalty to the central father. On the contrary, their collaboration and solidarity will prevent the emergence of such authority that prevents their becoming equal citizens since they must serve either as the mothers or daughters of the country.

As Kandiyoti indicates, tracing different formulations, treatments and transformations of a'woman question' provides an important field of analysis to discuss historical shifts in Turkish policy and the changing political priorities. ${ }^{68}$ The concept of 'negotiations of femininity' allows us to focus on the non-complete characteristics of feminine subjectivities constructed

\footnotetext{
${ }^{67}$ Nukhet Sirman, 'Writing the Usual Love Story', 256.

${ }^{68}$ Deniz Kandiyoti. 'Women and the Turkish state: Political actors or symbolic pawns', in Woman-Nation-State, ed. Nira Yuval Davis and Flora Anthias (London: Palgrave Macmillan, 1989), 126.
} 
within different formulations of this question and their being daily reconsidered and renegotiated. While the periods of significant political transformations intervene in these processes of renegotiation through offering new subjectivities for women, for the sake of sovereignty mechanisms that limit the destabilization of these new subjectivities are also introduced. Erdogan's presidentialism and Ihsanoglu's revised version of the parliamentary regime offer women in Turkey new roles and status through re-narrating the founding ideology of the state. However, these new roles attribute to them a mission to serve for the interest of the central authority as the mothers or daughters of the nation. Any subversion from these roles is depicted as disrespect for this status, which is constructed and controlled through references to the pain and suffering of their fellows. Demirtas on the other hand, in collaboration with the feminist women, constructs another narrative for women. His call for women's not becoming hostages of such state feminism and keeping the platforms of renegotiating official narrations of collective femininity via radical democratic measures is of critical importance in that sense.

\section{Disclosure statement}

No potential conflict of interest was reported by the authors. 